\title{
Development of the Rat Superior Cervical Ganglion: Ganglion Cell Maturation ${ }^{1}$
}

\author{
ERIC RUBIN ${ }^{2}$
}

Department of Physiology and Biophysics, Washington University School of Medicine, St. Louis, Missouri 63110

\begin{abstract}
The development of superior cervical ganglion cells has been studied in the fetal rat. Sympathetic cells appear first in thoracic sites and, one day later, in cervical sites; localized proliferation among these cells gives rise to the superior cervical and stellate ganglia. The maturation of superior cervical ganglion cells was examined by staining these neurons with horseradish peroxidase in fetal preparations maintained in vitro. This method showed that cells begin to extend processes at widely different times, without regard to a given cell's position in the ganglion. Postganglionic axons appear as early as day 12 of gestation (E12), when only a small number of ganglion cells have emerged from the mitotic cycle. The axon generally originates from a point on the ganglion cell body that is oriented toward the route of subsequent axon extension. As the postganglionic axons grow, they do not branch within the superior cervical ganglion and branch only to a slight extent, if at all, within developing peripheral nerves. Axonal growth is rapid, and fibers reach relatively remote sympathetic targets as early as E15. Dendrites first appear on E14 and are elaborated by ganglion cells that have already extended their axons. By the end of gestation, the number of primary dendrites found on some cells already falls within the range found in maturity.
\end{abstract}

Becausc neural development is often difficult to follow within the central nervous system, many investigations have focused on simpler peripheral systems such as the neuromuscular junction or autonomic ganglia. In mammals, the paravertebral chain of sympathetic ganglia has been particularly well studied. This system comprises a series of segmental ganglia whose preganglionic innervation arises from the spinal cord. Not only do the sympathetic ganglia contain relatively small numbers and few types of cells but, in maturity, the synapses formed upon the principal neurons are organ-

Received April 23, 1984; Revised August 17, 1984;

Accepted August 22, 1984

'I thank Dale Purves for his support and advice throughout this study, and C. J. Forehand, R. D. Hadley, J. W. Lichtman, and J. T. Voyvodic for comments on the manuscript. Expert technical help was provided by Emily Gordon, Pat Newton, and Dorothy Dill. Thanks also to Sue Eads and Jan Wuelling for typing the manuscript, and to Vicki Friedman for help with illustrations. This work was supported by grants from the National institutes of Health (NS-11699 and NS-18629), and from the Muscular Dystrophy Association to D. Purves.

${ }^{2}$ To whom requests for reprints should be sent, in care of Dr: D. Purves, at Department of Physiology and Biophysics, Washington University School of Medicine, St. Louis, MO 63110. ized according to well defined rules (Njå and Purves, 1977a; Lichtman et al., 1979; Purves and Lichtman, 1983).

Little is known about the developmental events that underlie this adult organization. In particular, the initial stages of sympathetic ganglion cell maturation and synapse formation remain largely unexplored. This series of studies examines prenatal development in the rat superior cervical ganglion. The present report demonstrates that even as neurons of the superior cervical ganglion coalesce, they extend axons to peripheral targets and soon afterward elaborate dendrites. The following papers (Rubin, 1985a, b) show that, simultaneously, a specific set of presynaptic axons grows into the ganglion and forms functional synapses. Thus, by birth, the ganglion is well developed in several respects, and substantial and appropriate synaptic connections have already formed. The timing of these events suggests possible mechanisms for establishing neural organization in the sympathetic system. Some of these results have been briefly reported (Rubin, 1982).

\section{Materials and Methods}

Preparation of fetal rats. Sprague-Dawley (Holtzman) rats were bred by placing individual males together overnight with three females. Sperm-positive females found the next morning were considered to be in day $O$ of gestation $(E 0)$; these rats generally gave birth early on E22 $(=P 0)$. The rate of fetal development matched the stages described by Christie (1964).

Pregnant rats were killed by cervical dislocation and fetuses were rapidly removed from the uterus and extraembryonic membranes. For experiments with living tissue, the fetuses were placed in a bath of oxygenated Ringer's solution at room temperature (Lichtman and Purves, 1980). Under these conditions, animals up to E16 could be maintained in good condition for as long as $10 \mathrm{hr}$ (see below).

Light microscopy. The overall development of the sympathetic system was followed from E11 through E16. Sagittal reconstructions were made with a camera lucida, using silver-stained paraffin sections (Levi-Montalcini, 1949).

The proliferation of cells in the right sympathetic chain was studied at the level of specific spinal segments by using each cervical and the first thoracic dorsal root ganglia as landmarks. Paraffin sections were cut at a thickness of $5 \mu \mathrm{m}$ in a plane generally transverse to the cervical axis and then were stained with thionin. Since the cervical region is flexed in the fetus, some of these sections were shifted from the true transverse orientation; therefore, the angle of section was taken into account in selecting sections that actually passed through defined segmental levels of the sympathetic system. For each cervical and thoracic level in a given fetus, several sections separated by at least $25 \mu \mathrm{m}$ were examined at $\times 625$. Cell nuclei within the sympathetic system were counted, and the average number of nuclei per cross-section was obtained for each segment. Such counts from three different animals were combined to obtain the mean number of cells per cross-section at a given segmental level on each day between E12 and E14. Mean nuclear diameter only increases from 4.5 to $5.0 \mu \mathrm{m}$ during this period; therefore, counts per cross-section have been compared without correction. Mitotic cells were also counted in these preparations.

Horseradish peroxidase labeling. The morphology of developing ganglion cells was determined on E12 by silver staining (see above). Cells on E13 and beyond were labeled with horseradish peroxidase (HRP; Sigma type VI) in isolated fetuses maintained in vitro as described above (see also Landmesser, 1978). Removing the lower jaw, heart, and lungs revealed the right dorsal aorta and aortic arches (E13 fetuses) or the common carotid artery (beyond E14: Barry, 1951). The superior cervical ganglion was cleaned by removing these vessels; the stellate ganglion was exposed by peeling away 
the pleural membrane at upper thoracic levels. Pressure injections of a $40 \%$ solution of HRP in $1 \%$ lysolecithin (Frank et al., 1980) were made with a micropipette ( $\sim 40 \mu \mathrm{m}$ tip diameter) directly into sympathetic ganglia. After peroxidase injection, the fetus was rinsed and immersed in fresh oxygenated Ringer's solution for 6 to $10 \mathrm{hr}$ at room temperature, as HRP diffused into neurons and their processes. This technique provides detailed and reproducible labeling of fetal sympathetic cells.

At the end of the diffusion period, fetuses were immersed in $1 \%$ paraform. aldehyde, $2.5 \%$ glutaraldehyde, $4 \%$ sucrose in $0.05 \mathrm{M}$ phosphate buffer $(\mathrm{pH}$ 7.3) for 12 to $16 \mathrm{hr}$ at $4^{\circ} \mathrm{C}$. They were then rinsed in $0.1 \mathrm{M}$ phosphate buffer over the next 2 days, embedded in rapidly fixed gelatin-albumin (Bowers and Zigmond, 1979), and sectioned at $50 \mu \mathrm{m}$ on a Vibratome. The HRP reaction product was developed according to the procedure of Hanker et al. (1977) in $0.1 \mathrm{M}$ phosphate buffer $(\mathrm{pH} 7.3)$ with a 10-min preincubation and a 7. to 10-min reaction period in the presence of $0.03 \% \mathrm{H}_{2} \mathrm{O}_{2}$. The sections were mounted on gelatin-albumin-coated slides freshly dipped in an alcoholic gelatin solution (Albrecht, 1954). Before drying completely, the slides were immersed in a $1: 1$ solution of $37 \%$ formaldehyde and absolute ethanol, a procedure that fixes sections firmly while avoiding cracks through delicate embryonic tissue (C. L. Smith, personal communication).
Larger HRP injections were made into the superior cervical ganglion to orthogradely label outgrowing postganglionic fibers. Additionally, HRP was injected into the eyes of some fetuses in vitro to determine by retrograde transport when axons of the superior cervical ganglion reached this site. Transport times of 7 to $10 \mathrm{hr}$ were generally used. Such experiments could not be carried out beyond E15 because the time required for HRP transport over longer pathways exceeded the period during which tissue could be adequately maintained in vitro.

Electron microscopy. Tissue was fixed by immersion. The cervical sympathetic system was exposed prior to fixation and later was removed and processed by itself. The fixative was a buffered mixture of glutaraldehyde $(3 \%)$, paraformaldehyde $(2 \%)$, and acrolein $(1 \%)$ (Kalt and Tandler, 1971). Tissue was postfixed either in osmium tetroxide, or osmium tetroxide and potassium ferricyanide (Langford and Coggeshall, 1980). The use of the acrolein fixative and ferricyanide during postfixation improved the preservation of fetal ganglia. After postfixing, tissues were embedded in Araldite. Thin sections were stained with uranyl acetate and lead citrate.

\section{Results}

The formation of the cervical sympathetic system. Sympathetic precursor cells first appear in the cervical region on day 12 of
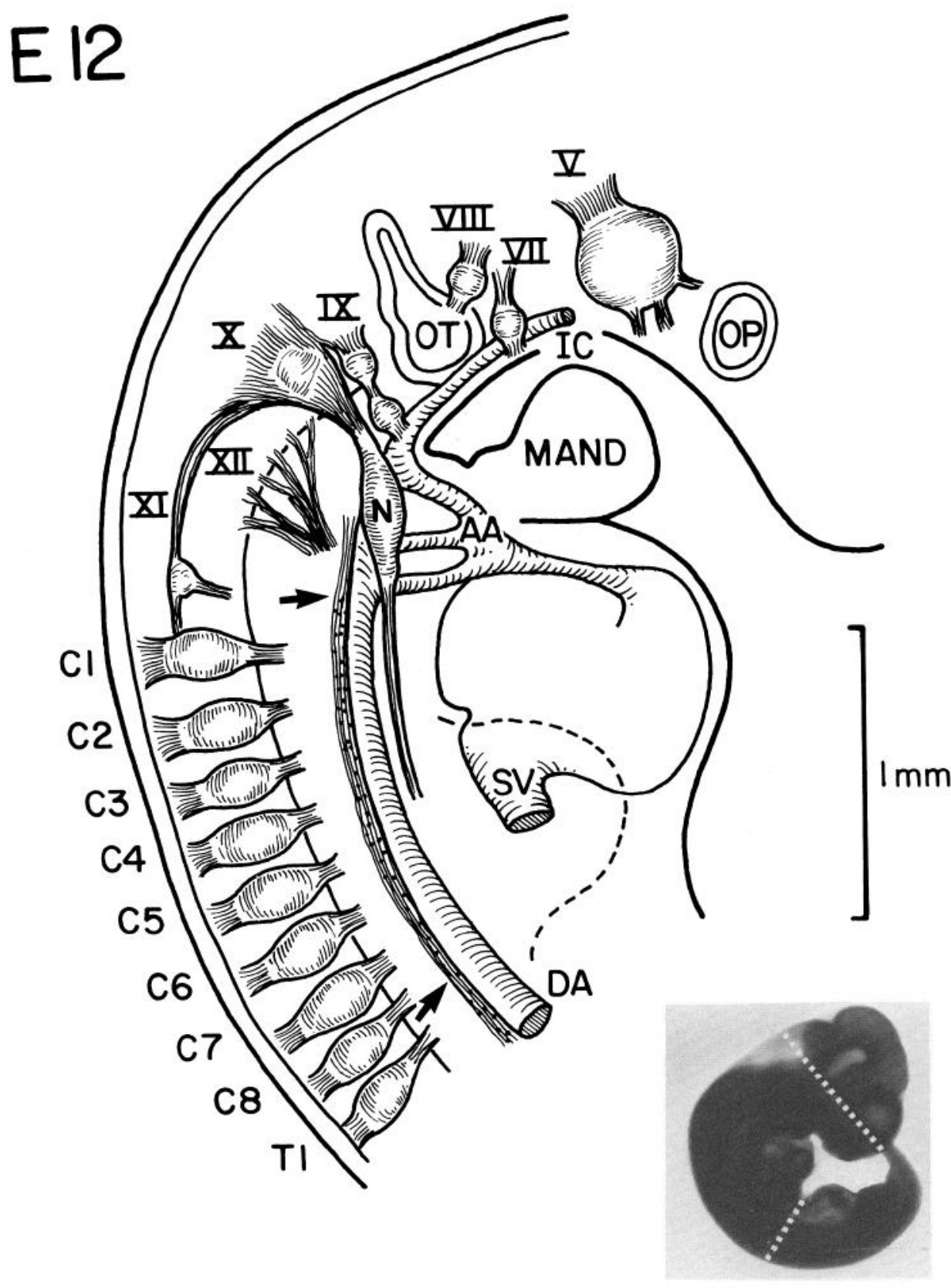

Figure 1. The cervical sympathetic system on $\mathrm{E} 12$ (sagittal view; reconstructed from silverstained sections). At this age, the cervical component of the sympathetic system (arrows) is a uniform column of cells and fibers which lies along the dorsal aorta $(D A)$. The sympathetic cells are diffusely organized in comparison to other neural crest-related tissues in the region, such as the nodose ganglion $(N)$ and the nearby dorsal root ganglia. However, a rudimentary postganglionic nerve (the internal carotid nerve) is already present (rostral to upper arrow; see Fig. 7). Histological views of the E12 sympathetic system are shown in Figure 3. Inset, Photograph of a whole E12 embryo, in the same orientation; dotted lines indicate boundaries of the reconstruction. Roman numerals, cranial nerves and ganglia; AA, aortic arches $(3,4$, and 6 ); $C 1$ to $T 1$, segmental levels based on dorsal root ganglia; IC, internal carotid artery; MAND, mandible; $O P$, optic stalk; $O T$, otocyst; $S V$, sinus venosus. The dashed line indicates the forelimb bud. 


\section{THORACIC}

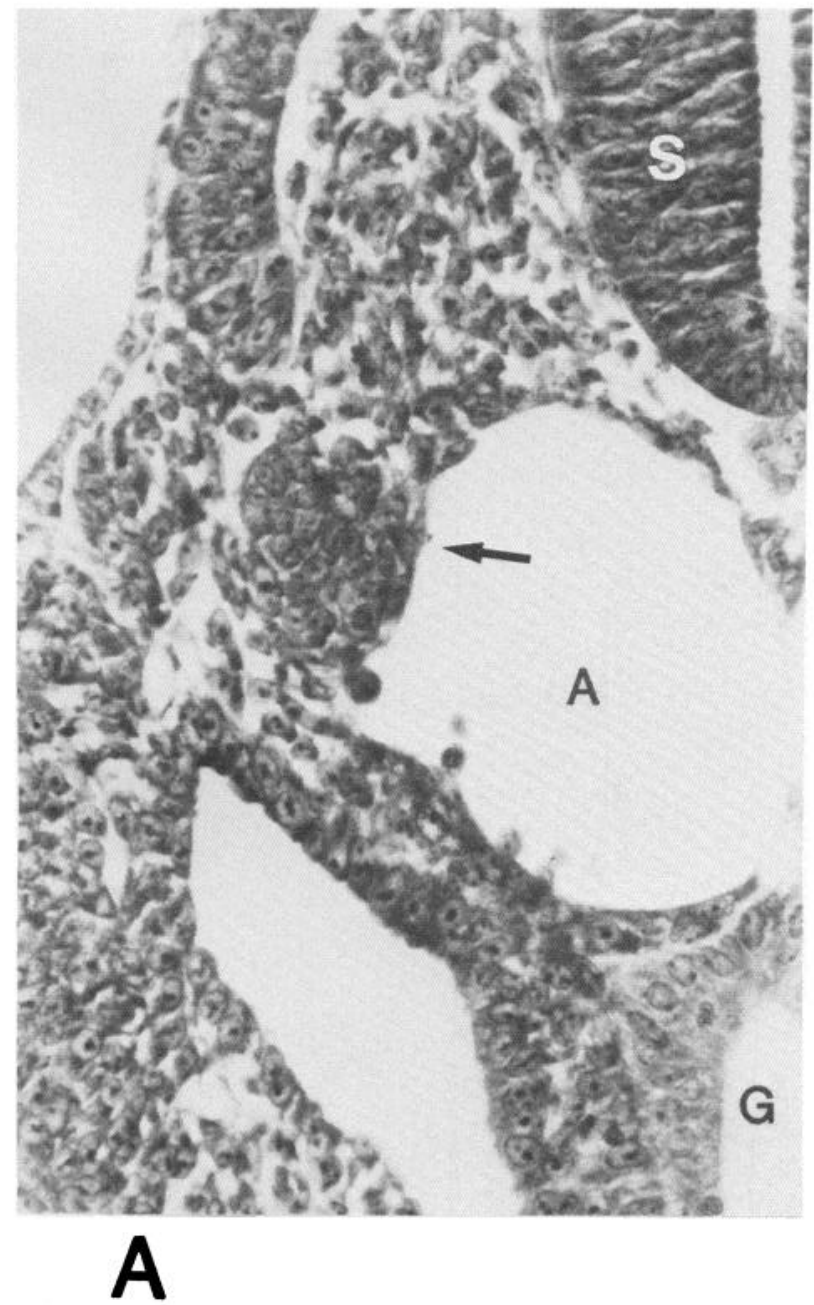

CERVICAL

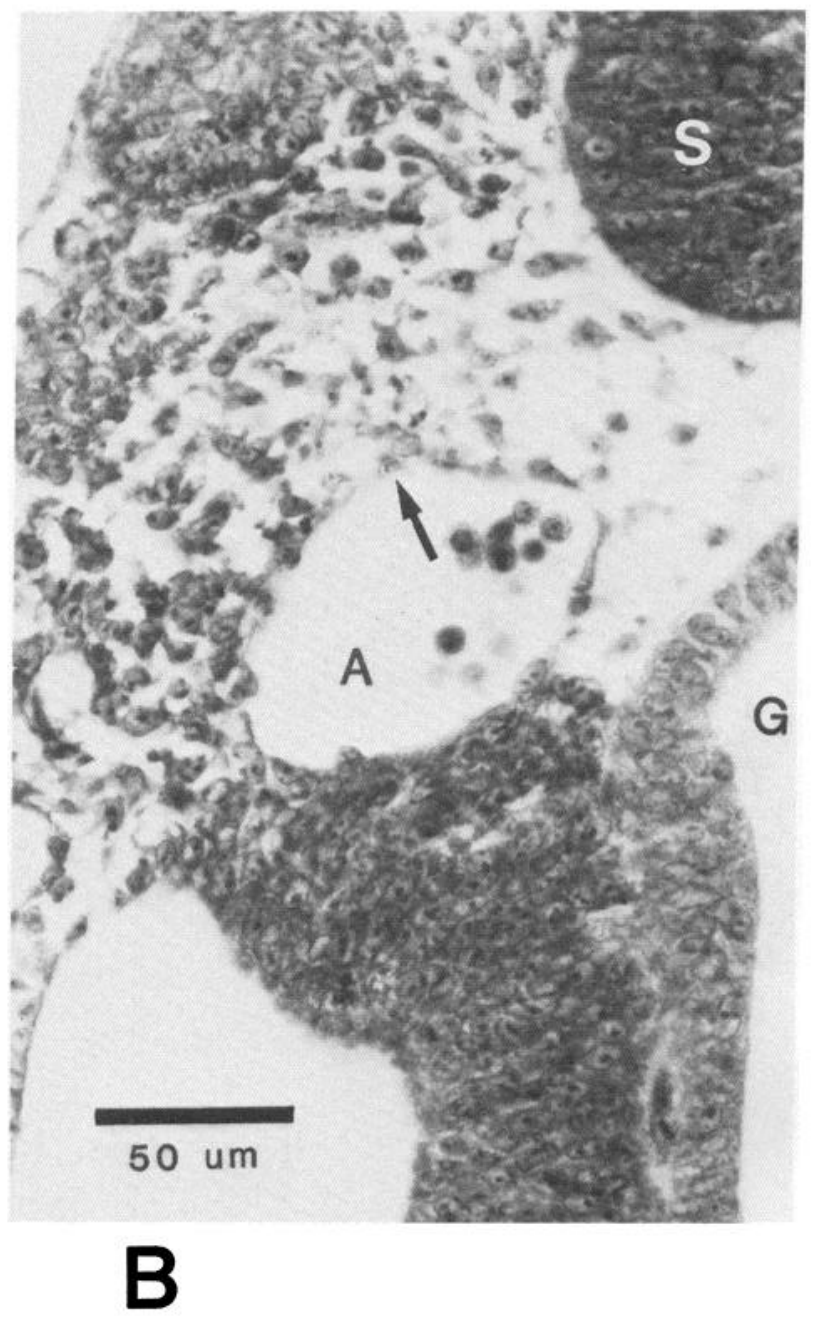

Figure 2. The appearance of the paravertebral sympathetic system on E10/11 (transverse sections). $A$, In the upper thoracic region, cells have begun to accumulate along the aorta in the characteristic position of the sympathetic chain (arrow). B, In contrast, at cervical levels, very few cells have reached the corresponding site (arrow). The sequence in which the cervical and thoracic components of the sympathetic system appear does not conform to the general rostral-to-caudal progression of development (see "Discussion"). $A$, aorta; $G$, lumen of gut; $S$, spinal cord.

gestation (E12) as a uniform column along the dorsal aorta at all cervical levels (Fig. 1). One day earlier (E10/11), similar cells are found along the aorta only at thoracic levels (Fig. 2), indicating that cells of the cervical sympathetic system reach their general destination later than cells of the thoracic component. Between E12 and E14, cells accumulate adjacent to cervical segments 1 to 5 (C1 to C5), forming the primitive superior cervical ganglion (Fig. 3). Cells remain scarce at slightly more caudal cervical levels, creating a narrow region which later becomes filled with axons (the cervical sympathetic trunk). Further caudally, the stellate ganglion forms at the lowest cervical and upper thoracic levels. This progressive change in cell distribution can be followed by counting cells adjacent to each cervical segment as a function of time (Fig. 4).

The accumulation of cells to form the superior cervical and stellate ganglia reflects enhanced proliferation in these sites. Although the cervical sympathetic system shows a high overall frequency of mitosis on E14, the mitotic index is especially high at upper and lower cervical levels (Fig. 5; see also Fig. 3). In contrast very little proliferation occurs at the level of C6. As the cervical and upper thoracic ganglia accumulate cells, the cervical sympathetic trunk elongates in conjunction with the growing fetus, presumably by the growth of the axons within the trunk; however, the superior cervical ganglion itself does not lengthen proportionately. On E14 the ganglion extends from $\mathrm{C} 1$ to $\mathrm{C} 5$, whereas on $\mathrm{E} 16$ it only spans segments C1 to C3 (Fig. 6). This apparent shrinkage actually reflects about a $20 \%$ elongation of the ganglion, whereas the overall distance between $\mathrm{C} 1$ and $\mathrm{C} 6$ more than doubles between E14 and E16. The small change of length of the superior cervical ganglion indicates that the cells generated in this region aggregate rather than disperse along the lengthening cervical sympathetic trunk.

On E14, some cells remain scattered between the emerging superior cervical and stellate ganglia (Fig. 4); evidence presented below shows that many of these cells are neurons. As the ganglia consolidate and the cervical sympathetic trunk becomes distinct, such cells sometimes form small aggregates along the trunk. These clusters apparently result from irregularities in the proliferation and/ or coalescence of the ganglion cells initially found in the trunk, and probably give rise to the accessory ganglia found along the cervical sympathetic trunk in some mammals (Douglas et al., 1960). However, accessory ganglia occur infrequently in the mature rat, and, indeed, by E20 the cervical trunk is dominated by axons and largely free of cells. Electron microscopy showed that many of the cells remaining in the trunk on E20 have begun to ensheath axons and thus appear to be young Schwann cells. Other cells in the trunk at 

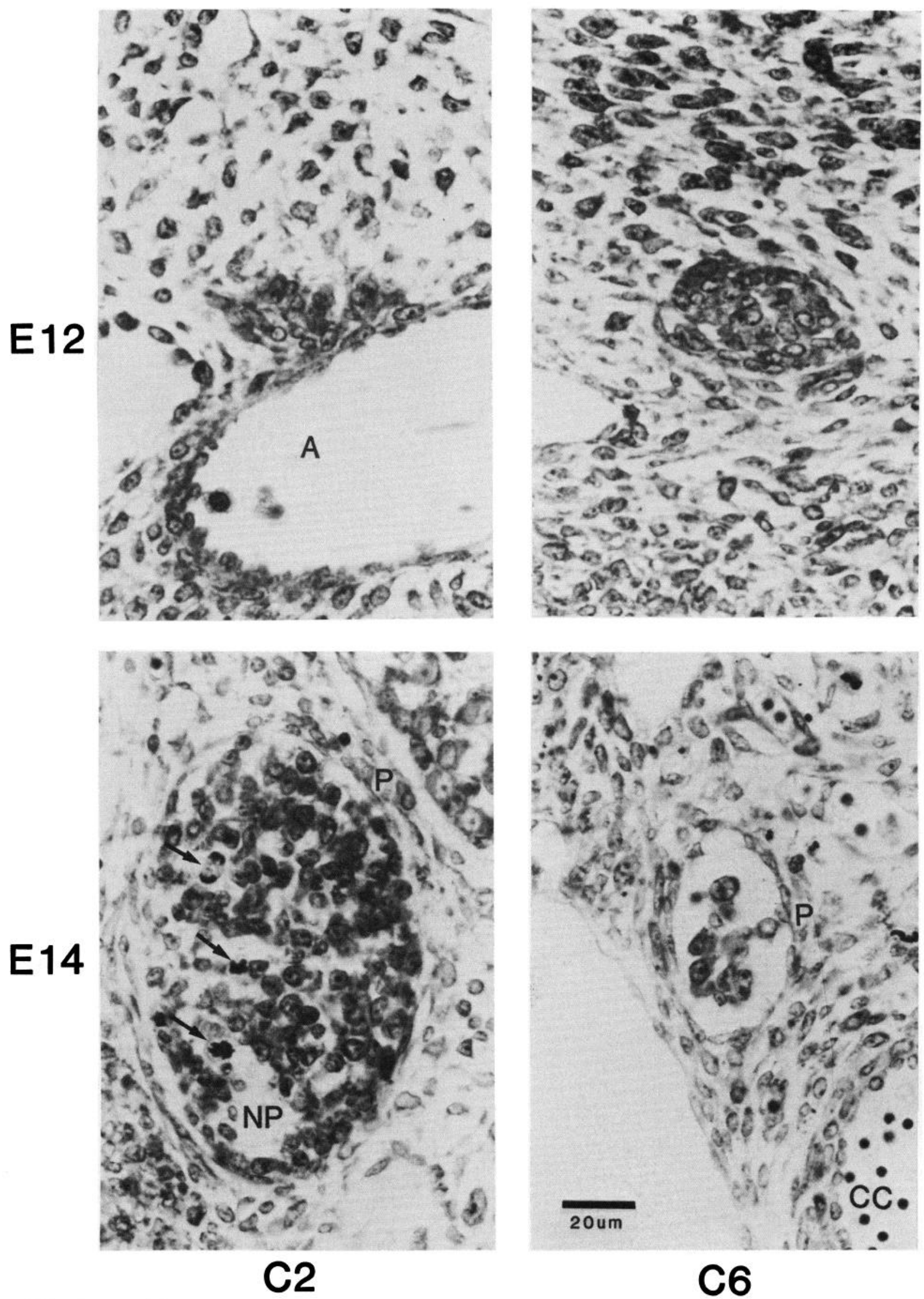

Figure 3. Development of the cervical sympathetic system. Transverse paraffin sections stained with thionin. Left, Cell accumulation at the level of the second cervical segment (C2). On E12 (top) few cells are found in the sympathetic position (cf. Fig. 2B); by E14 (bottom) many more cells are present and mitotic figures (arrows) are common. Right, Cells at the level of C6. On E12, similar numbers of sympathetic cells are found at levels C6 and C2. Between $\mathrm{E} 12$ and E14, however, the number of cells at level $\mathrm{C} 6$ does not increase as at $\mathrm{C} 2$ and may actually decrease. Electron microscopy of comparable material on E14 shows that the apparently empty spaces surrounding the cells at level C6 are filled with longitudinally oriented axons (see Rubin, 1985a). By E14, a distinct perineurium $(P)$ surrounds the sympathetic system. $A$, aorta (the forerunner of the common carotid artery $(C C)$ ); Barry, 1951); NP, neuropil. Calibration bar applies to all panels. 


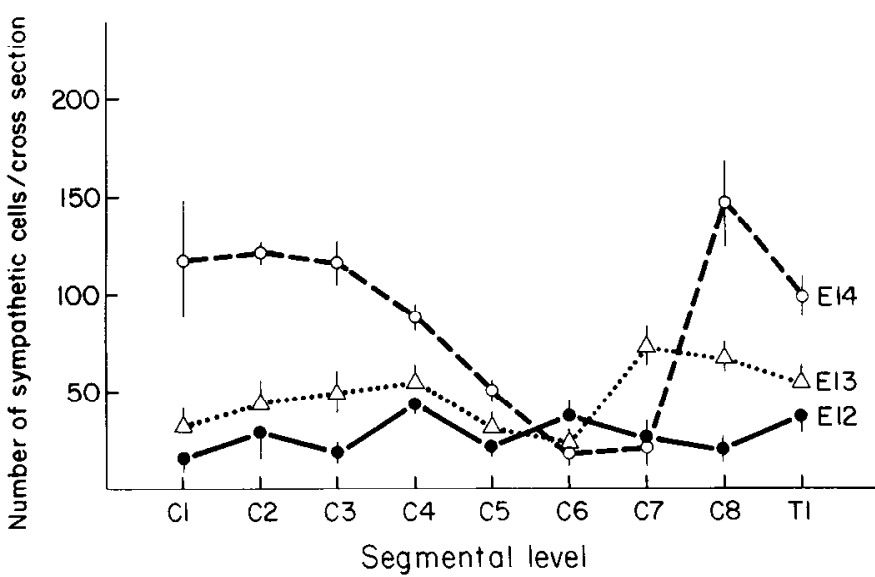

Figure 4. The distribution of sympathetic cells in the cervical region. $\mathrm{C1}$ to $T 1$ are levels of the sympathetic system defined by the location of dorsal root ganglia. Each point is the mean value \pm SEM from three animals at each age (see "Materials and Methods"). Between E12 and E14, the number of cells increases markedly at levels $\mathrm{C} 1$ to $\mathrm{C} 4$ and below $\mathrm{C} 7$, the sites of the superior cervical and stellate ganglia, respectively. At $\mathrm{C} 6$ the cell number is stable or somewhat reduced (see also Fig. 3 ).

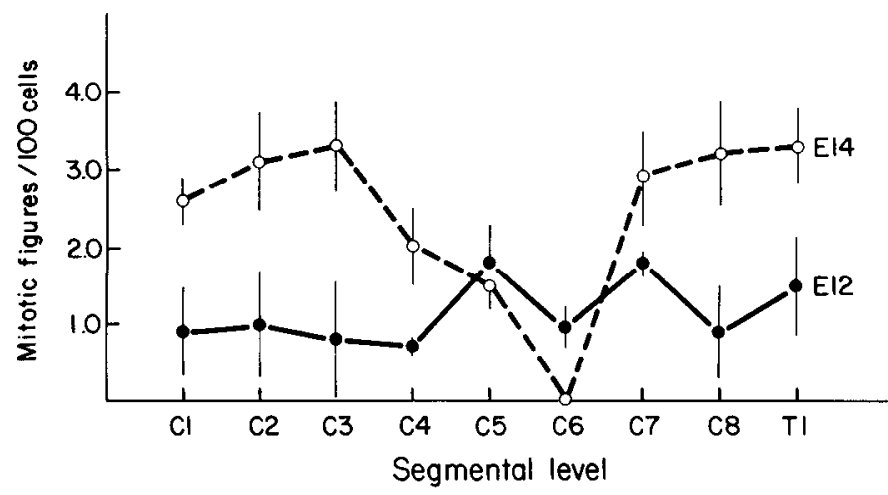

Figure 5. Mitotic frequency along the cervical sympathetic system on E12 and E14. Cells were counted as in Figure 4. Each point represents the mean frequency \pm SEM in a population of at least 160 cells, pooled from three animals at each age. Cells proliferate most vigorously in the sites of the future ganglia and minimally in the region of the emerging cervical sympathetic trunk (around segment $\mathrm{C} 6$ ).

this age are probably Schwann cell precursors, which proliferate primarily after birth (Terry et al., 1974).

The apparent prenatal loss of neurons from the cervical sympathetic trunk could reflect either cell death or cell migration out of this nerve. However, there was no clear evidence of degeneration in the cervical sympathetic system at either the light or the electron microscopic levels before E20, the period of cell depletion (cf. Wright et al., 1983). Furthermore, a distinct perineurium surrounds the cervical trunk after $\mathrm{E} 14$; in the electron microscope, no cells could be seen crossing this sheath at any segmental level. Simple dilution of neurons within the increased bulk of the cervical trunk may also contribute to the apparent loss of these cells, but other evidence suggests that some neurons leave the trunk by moving longitudinally within it, into the adjoining ganglia (see "Discussion").

The growth of axons from superior cervical ganglion cells. Some ganglion cells in the cervical region have already extended processes by E12 (Fig. 7). Silver staining showed that only one process arises from a given ccll at this agc; otherwisc the soma is smooth. The neurites of many cells end within the ganglion on E12, but some cells already bear long fibers that generally follow linear courses and resemble postganglionic axons. Their identification as axons was confirmed by the finding that some of these fibers already extend beyond the ganglion on E12 and have begun to form postganglionic nerves (Fig. 7). Ganglion cells thus seem to develop axons before

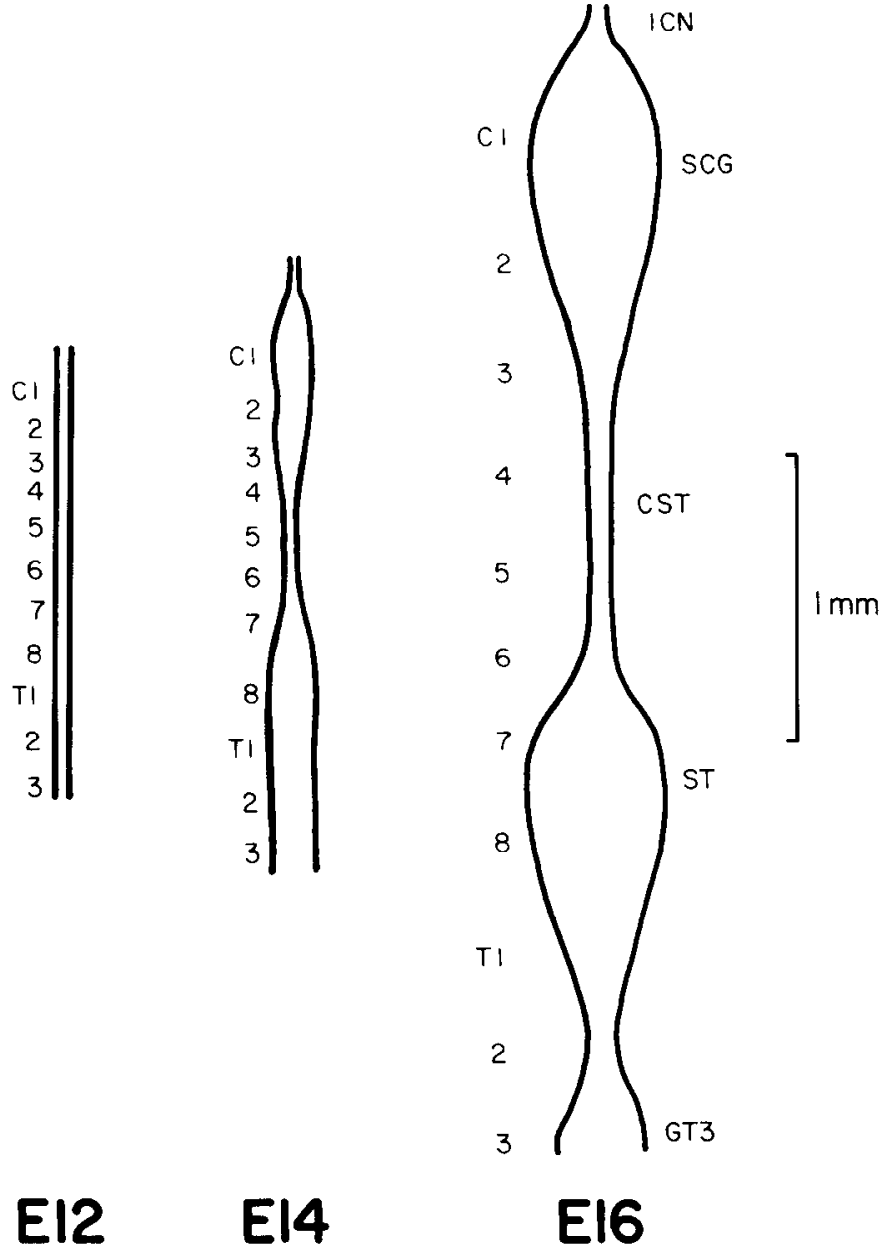

Figure 6. Growth and coalescence in the cervical sympathetic system, E12 to E16. Drawings are based on measurements of width at each segmental level; a sagittal orientation is shown. Segmental designations $(\mathrm{C} 1$ to $8, T 1$ to 3 ) refer to the locations of adjacent dorsal root ganglia. Elongation occurs primarily within the cervical sympathetic trunk (CST), whereas the superior cervical gnglion ( $S C G$ ) lengthens only slightly. The cervical sympathetic trunk loses cells but actually thickens as preganglionic axons accumulate over time (see Rubin, 1985a). ICN, internal carotid nerve; ST, stellate ganglion; GT3, ganglion of segment T3. The calibration bar applies to the entire figure.

other processes, and some cells begin this growth by the time they reach the cervical region.

Developing ganglion cells were also studied using the marker HRP to provide Golgi-like staining of cell bodies and their processes (see "Materials and Methods"). Ganglia could first be injected with HRP on E13; at this age, such staining showed that ganglion cells closely resemble the cells stained with silver on E12 (Fig. 8; cf. Fig. 7). Even on $\mathrm{E} 13$, neuronal somata bear no processes other than the axon and occasional small protrusions opposite the axonal origin.

The direction of axon extension varies as a function of the longitudinal position of cells in the ganglion (Fig. 9). On E14, HRP injected into the most rostral portion of the superior cervical ganglion labeled many rostrally projecting neurons. Most of these cells were clustered near the injection site, although labeled neurons could be found throughout the ganglion and occasionally in the primitive cervical sympathetic trunk. In ncarly all cases, rostrally projecting cells extend their axons directly from the rostral side of the soma (Fig. 8; see also Fig. 13); axons emerging from other somatic sites turn rostrally within one or two cell body diameters (Fig. 7C). In contrast, when HRP injections were placed in the caudal pole of the ganglion on E14, a different population of cells and their axons were filled. These cells, few in number, occur predominantly in the caudal 


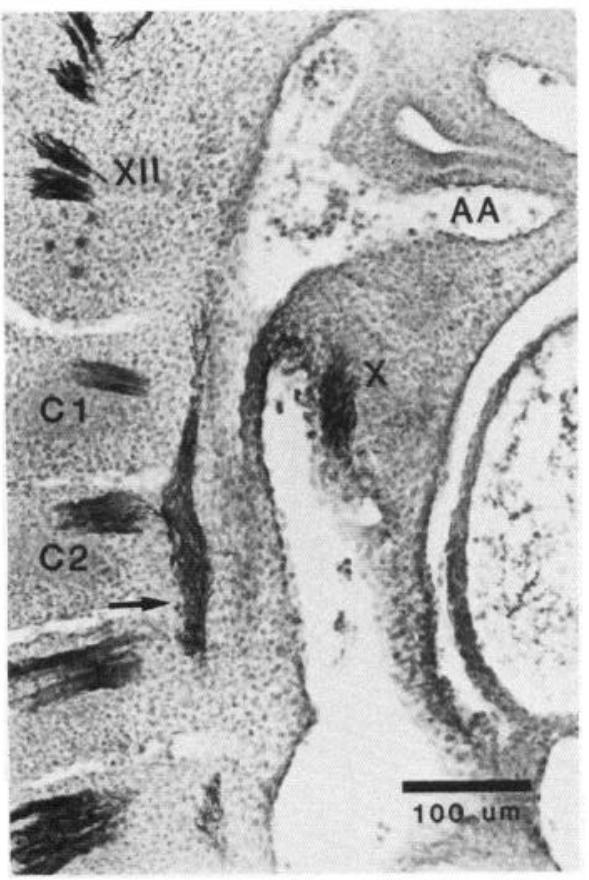

A

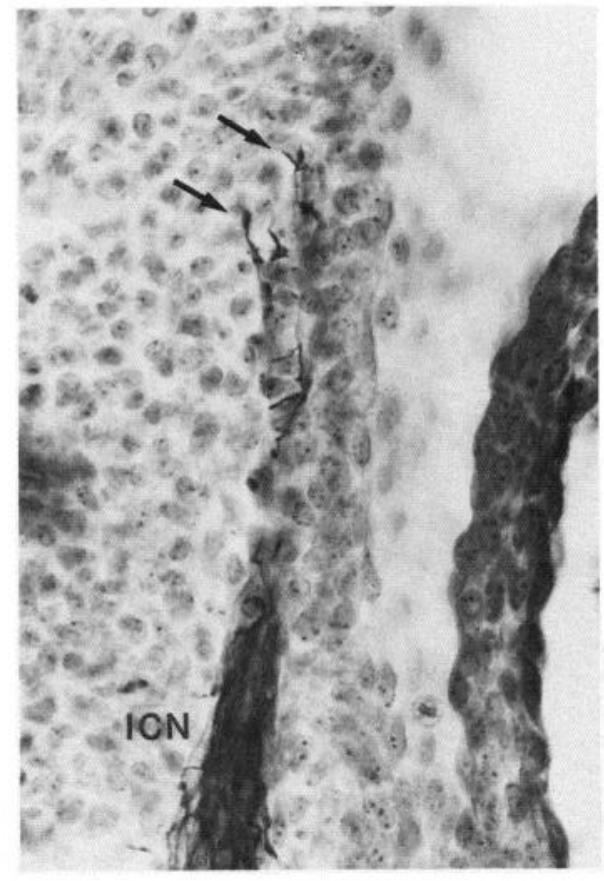

B

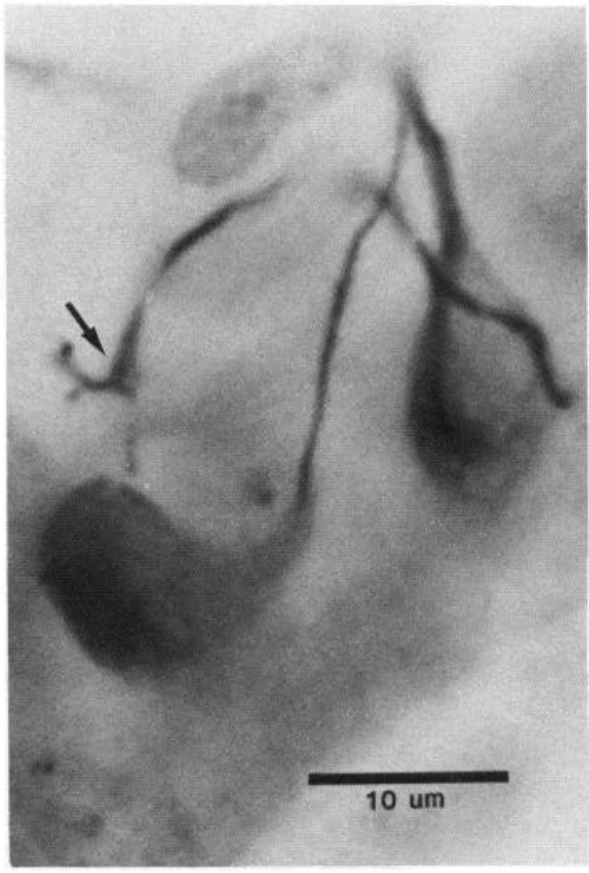

C

Figure 7. Early extension of axons from sympathetic ganglion cells on E12 (silver stain). A, Sagittal view, orientation as in Figure 1. The primitive cervical sympathetic system (arrow) lies dorsal to the aorta and, in serial sections, spans all of the segments of the cervical region. $X$ and $X I I$, cranial nerves; $A A$, aortic arch. $B$. Detail of $A$. The cervical sympathetic system is filled with silver-stained axons. Some of these fibers extend rostrally beyond the ganglion, forming the primitive internal carotid nerve (ICN). Arrows, tips of postganglionic axons within the mesenchyme, probably growth cones. $C$, Examination of individual cells confirms the development of postganglionic axons; a single process emerges from each silver-stained cell body. Some of these fibers end within the ganglion in structures that presumably are axonal growth cones (arrow). Other axons can already be traced into postganglionic nerves.

part of the superior cervical ganglion and occupy a more restricted territory than do the cells labeled from a rostral injection. The axons of such cells generally emerge from the caudal aspect of the soma. In summary, by E14, cells throughout the ganglion project rostrally, whereas caudally projecting cells lie primarily in the caudal part of the ganglion. This is the same general pattern found in the adult (Purves, 1975; Bowers and Zigmond, 1979).

Further labeling experiments showed that many of the cells still occupying the cervical sympathetic trunk on E14 are neurons. These cells project rostrally or caudally in about equal numbers; their axons traverse the cervical trunk to enter the superior cervical or stellate ganglia and then join postganglionic nerves. In maturity, cells with such projections are rarely found within the trunk but, instead, are concentrated in the zones where the trunk enters the superior cervical or stellate ganglia (Bowers and Zigmond, 1981).

The development of peripheral projections. The axons of most superior cervical ganglion cells extend rostrally (Fig. 9) and emerge from the rostral pole of the ganglion to grow along the major branches of the carotid artery, establishing the internal and external carotid nerves. The number of postganglionic axons rapidly increases: on $\mathrm{E} 12$ the internal carotid nerve has only begun to form (Fig. 7), but by $E 15$, this nerve contains about 5000 axon profiles (counted with the electron microscope, just distal to the superior cervical ganglion). As seen in the light microscope, postganglionic axons do not appear to branch within the ganglion or within peripheral nerves (shown, respectively, by retrograde and orthograde HRP labeling). Consistent with this observation, the endings of fetal postganglionic axons within peripheral nerves are generally straight; the processes of the growing tips show little deviation away from the dominant direction of axon growth (Fig. 10). Indeed, most growing axons appear to pass through peripheral nerves parallel to and in very close contact with previously extended postganglionic fibers (Fig. 11). In contrast, the tips of postganglionic fibers that diverge from peripheral nerves give off widely radiating processes within the mesenchyme of the head (Fig. 10).

As the postganglionic axons grow into the periphery, their route shifts from arterial branches to cranial nerves. The pathways taken by the postganglionic axons seem organized according to the adult projection from the outset; for example, even the first postganglionic fibers to reach the lacrimal gland emerge from the superior cervical ganglion in the internal carotid nerve, transfer to the facial nerve near the geniculate ganglion, and follow a branch of this nerve into the orbit (Fig. 12). Labeled postganglionic fibers could be traced to the lacrimal gland as early as E15, indicating rapid outgrowth of these axons from the superior cervical ganglion. The timing of this growth was confirmed by retrograde labeling from postganglionic targets. No labeled cells were found in the superior cervical ganglion following injections of HRP into the eye on E14 ( 8 to $10 \mathrm{hr}$ survival); however, similar injections on E15 labeled a small number of cells, primarily in the rostral half of the ganglion. Older fetuses could not be adequately examined using in vitro injections (see "Materials and Methods"), but on the day of birth, injection of HRP into the eye of intact pups (24 hr survival) labeled numerous superior cervical ganglion cells, again localized to the rostral part of the ganglion. Since postganglionic fibers have reached targets as far away as the eye by E15, more proximal end organs (e.g., smooth muscle of the carotid arteries) probably receive postganglionic projections even earlier.

Dendritic development in the superior cervical ganglion. Cells on E13 are essentially smooth, except for the points where axons emerge (Fig. 8). By E14, however, many ganglion cells bear a number of processes in addition to their axons (Fig. 13). The longer of these processes are presumably young dendrites. The dendrites emerge in no particular spatial relationship to a cell's axon, although sometimes a dendrite and axon stem from a common process. Even on E14, the dendrites of fetal ganglion cells differ from postganglionic axons in that they become narrow close to the cell body, follow irregular trajectories, and branch frequently. By birth, dendrites 


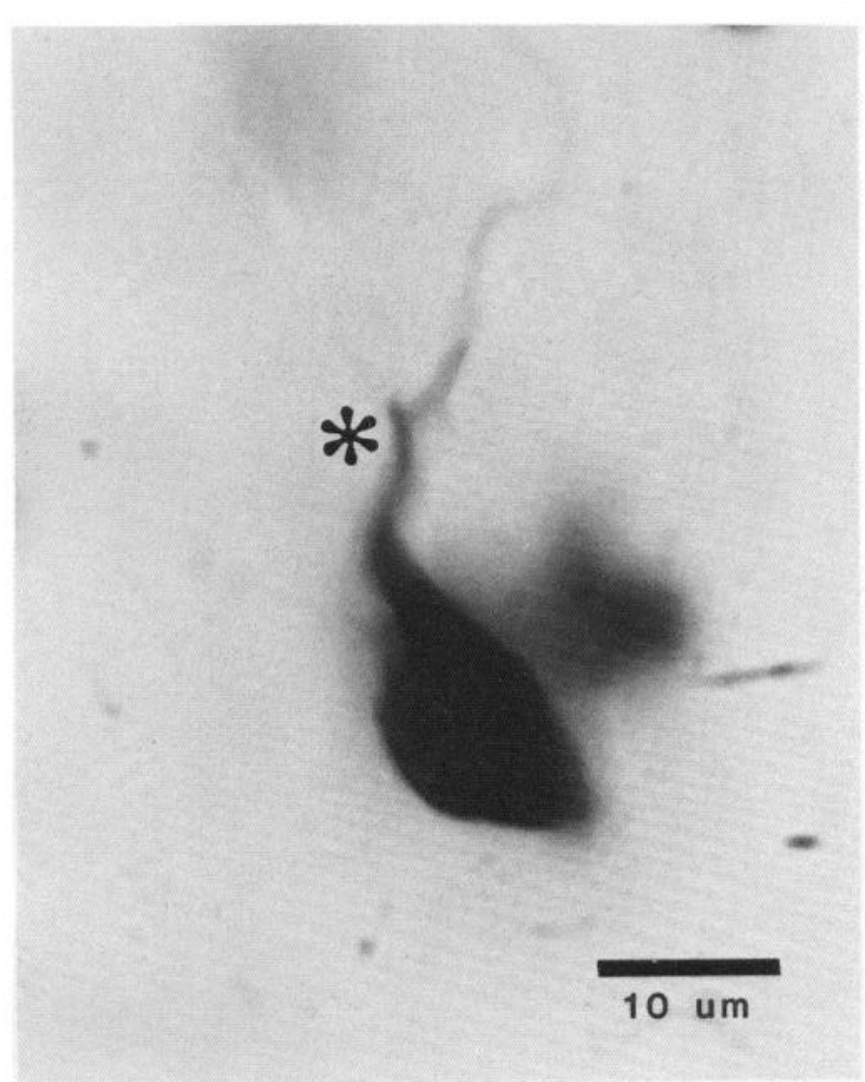

Figure 8. A cell in the superior cervical ganglion on $E 13$, retrogradely labeled with HRP. This cell was completely contained within one $50-\mu \mathrm{m}$ section. A single process, the postganglionic axon (*), emerges from the cell body, which is otherwise smooth. The axon extended rostrally to the HRP injection site in the rostral pole of the ganglion. In most cases, as illustrated here (see also Fig. 13), axons were found to emerge from cell bodies already oriented in the ultimate direction of axon growth. A second labeled cell lies out of focus in the background.

\section{El4}

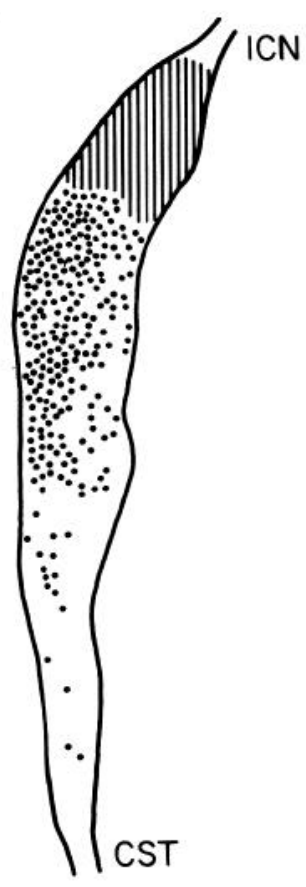

A

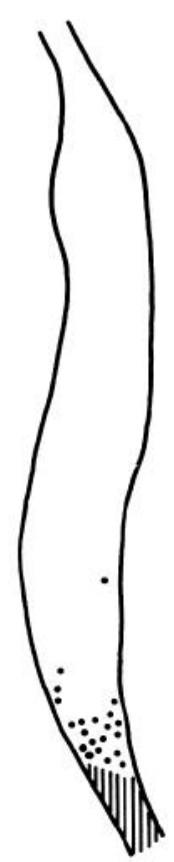

500 $\mu \mathrm{m}$

Figure 9. Camera lucida reconstructions of sagittal sections showing the distribution of superior cervical ganglion cells on E14 projecting rostrally $(A)$ and caudally $(B)$. HRP was injected near the base of the internal carotid nerve (ICN) or the cervical sympathetic trunk (CST), as indicated by shading. Each dot represents one labeled cell; overlapping cells near the injection sites have been omitted for clarity. Rostral is toward the top of the figure. The projection pattern on $\mathrm{E} 14$ resembles that found in the adult (see the text).
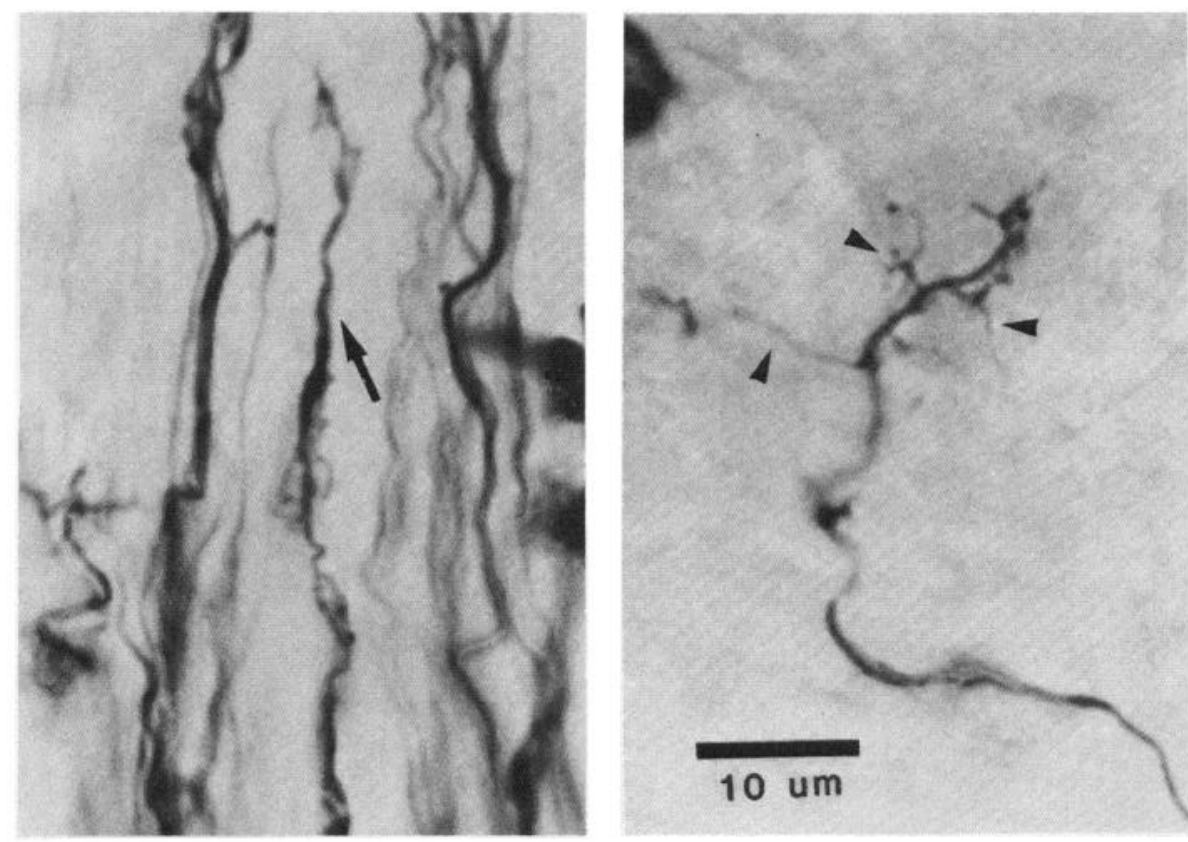

A
Figure 10. Developing postganglionic axons of the internal carotid nerve on E14. Orthograde HRP labeling from the superior cervical ganglion. $A$, A longitudinal section through the nerve, showing what appears to be the tip of a labeled axon (arrow). Within the nerve, such growing ends are generally aligned with the axis of their parent fibers and show little lateral extension. $B$, An axon that has diverged from the nerve into the mesenchyme of the head. Here the presumed growth region at the fiber's tip gives off more widely distributed processes (arrowheads). The calibration bar applies to both $A$ and $B$. 


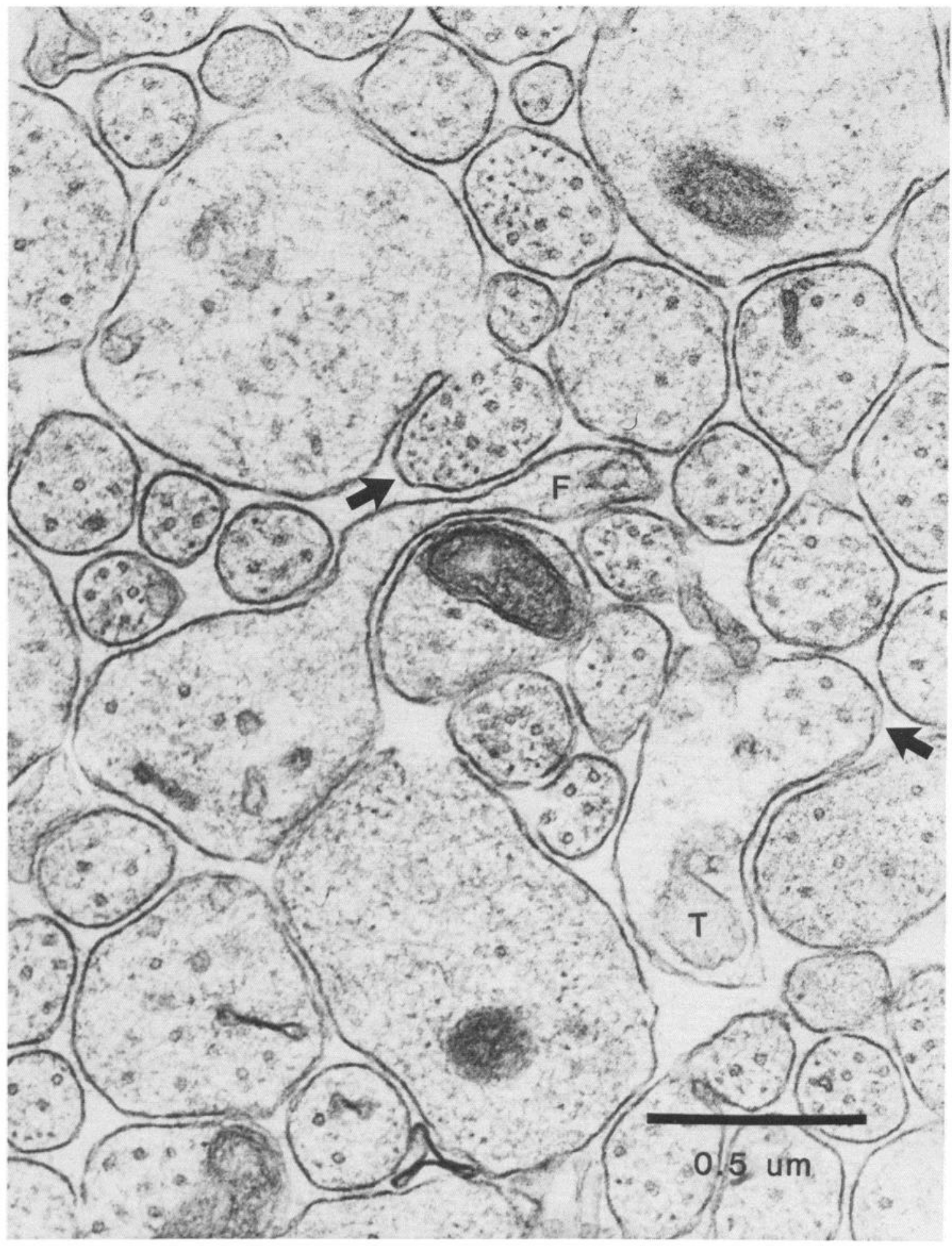

Figure 11. An electron micrograph showing the close association of postganglionic axons on E15 (transverse section of the internal carotid nerve). Little extracellular material intervenes between these fibers. Expanded profiles (arising from axons, arrows) with filaments, tubular inclusions ( $T$ ), and apparent filopodia $(F)$ may correspond to presumed growth cones seen at the light microscopic level (Fig. 10; see Tennyson, 1970).

have emerged from nearly all of the ganglion cells that could be retrogradely labeled with HRP from the base of the internal carotid nerve. The most mature neonatal cells (those cells with proximal dendrites of the caliber illustrated in Fig. 13; P0) possess from 3 to 10 primary dendrites. However, some neurons in the neonatal ganglion apparently are still very immature, as occasional cells at this age resemble cells typical of E12 to E14; that is, they possess axons but show little dendritic development. This finding indicates that neuronal maturation is asynchronous in the ganglion.

Maturation of cells as a function of their position within the ganglion. To judge from the criteria of mitotic rate and time of axon and dendrite initiation, there is no obvious gradient of neuronal development within the superior cervical ganglion. As cells coalesce, a relative enhancement of mitotic rate occurs at the level of $\mathrm{C} 2$ and 


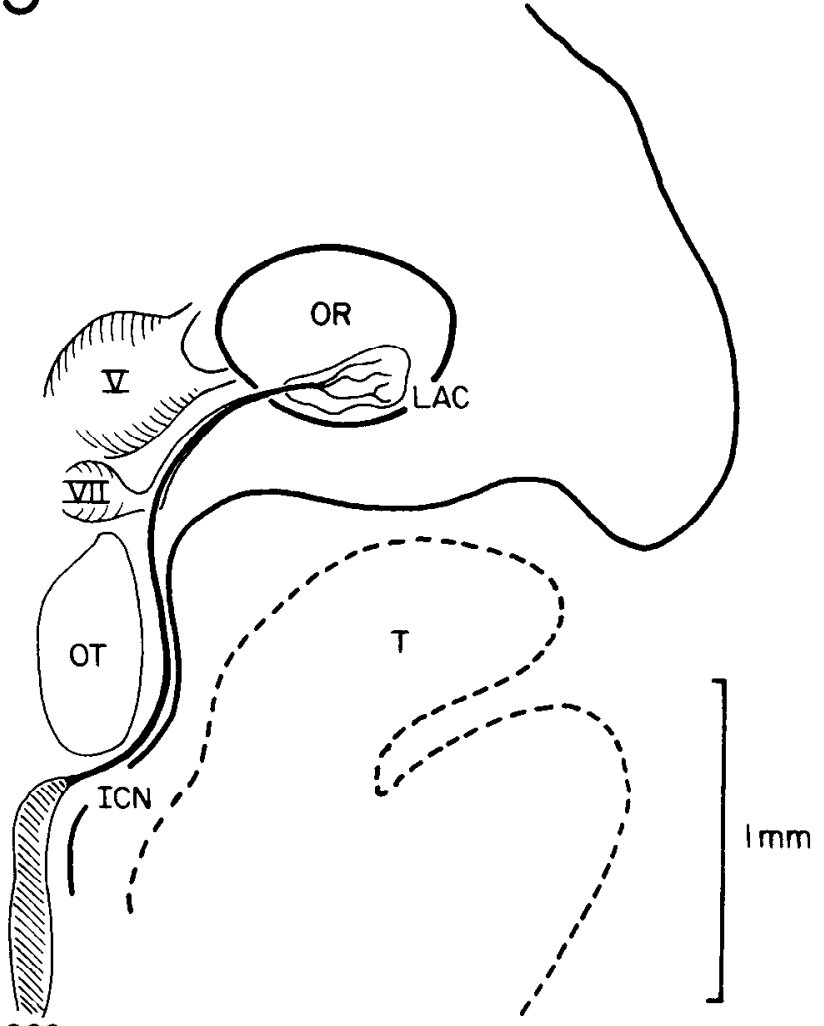

SCG

Figure 12. Growth of postganglionic axons into peripheral tissues, as shown by orthograde labeling from the superior cervical ganglion on E15. Camera lucida reconstruction in the sagittal plane. Labeled axons pass from the superior cervical ganglion (SCG) into the internal carotid nerve (ICN), and finally into a branch of the facial nerve distal to the geniculate ganglion (VII). The labeled fibers ramify within glandular tissue of the orbit. LAC, inferior lobe of the lacrimal gland; $O R$, orbit; $O T$, otic vesicle; $T$, tongue; $V$, trigeminal ganglion.

C3, but this longitudinal difference within the ganglion is small compared to the dramatically different rates of proliferation seen between ganglionic and non-ganglionic portions of the sympathetic system (see Fig. 5). Mitotic activity within the ganglion also appears to be evenly distributed in the transverse axis. In accord with this uniform pattern of cell generation, neurons at the same stage of dendritic development can be found throughout the ganglion at any given age. Thus, when dendrites first appear (E14), they are found on cells spread widely across the ganglion. Other cells initiate dendrites only at the end of fetal development (see "Dendritic Development in the Superior Cervical Ganglion"); these cells, too are found in all regions of the ganglion.

\section{Discussion}

The small size of the fetal rat sympathetic system allows HRP to be used to study the development of both axonal projections and dendritic morphology (see also Rubin, 1985a). The information derived from such experiments, as well as the results of more conventional anatomical procedures, clarify some of the early developmental events in the sympathetic system.

The source of superior cervical ganglion cells. The precursors of sympathetic ganglion cells originate in the neural crest (reviewed by LeDouarin, 1982). The present study shows that sympathetic precursor cells in the rat first reach paravertebral sites between E10 and E11 (Fig. 2; see also Cochard et al., 1979).

Cells of the neural crest migrate and differentiate in a generally rostral-caudal sequence (LeDouarin, 1982). However, in the rat the sympathetic system first forms at upper thoracic rather than cervical levels; the cervical component appears a day later as a meager and diffusely organized structure (Figs. 1 and 2; see also Mihalik, 1940; Lutz, 1968; Fernholm, 1971). The delayed appearance of the cervical sympathetic system could be due to a retarded ventral migration of the cervical neural crest, but on E11, nearby structures such as the cervical dorsal root ganglia and the nodose ganglion (which arise in whole and in part, respectively, from cervical neural crest; D'AmicoMartel and Noden, 1983) have already formed. A more reasonable explanation for the delay in cervical sympathetic development is that the ganglion cells of this region originate from a non-cervical source. Given its proximity and earlier appearance, the upper thoracic sympathetic chain (derived from trunk crest; Weston, 1963) is the most probable source of these cells. Apparently, the precursors of cervical sympathetic cells originate in trunk crest, transiently occupy thoracic paravertebral sites, and then move longitudinally into the cervical region.

Longitudinal movement in the developing sympathetic system is indicated by other evidence as well. In the chick, some cells of the neural crest settle in sympathetic ganglia several segments away from their level of origin (Yip, 1983). Furthermore, cells of the chick sympathetic system migrate up to six segments rostrally or caudally to fill in deletions caused by partial ablation of the neural crest (Hammond and Yntema, 1947). Finally, some experiments in the chick seem specifically to indicate that cells of the superior cervical ganglion derive from more caudal levels of the neural crest, although gross morphogenetic movements in the embryo may also contribute to this apparent displacement (LeDouarin, 1982).

Proliferation and aggregation of ganglion cells. Starting from a narrow column of cells on E12, the cervical sympathetic system grows rapidly. Localized mitotic activity creates concentrations of cells that become the superior cervical and stellate ganglia (Fig. 5). The persistently low mitotic index around the level of $\mathrm{C} 6$ accentuates the separation between the ganglia developing above and below this level. It is likely that most of the cell division seen in the ganglion between E12 and E14 occurs among neuronal rather than glial precursors (Terry et al., 1974; Hendry, 1977). Thus, the distribution of ganglion cells in the sympathetic chain seems based at least in part upon an early regional enhancement of neuronal proliferation (see also Altman and Bayer, 1982).

The accumulation of superior cervical ganglion cells may be augmented by aggregation, since cells in the developing ganglion remain close together as the sympathetic systom longthens. At the same time, the ganglion appears to incorporate some neurons initially occupying the cervical sympathetic trunk. On E14, the postganglionic axons projecting through the cervical trunk originate from cells that lie all along this nerve, whereas in maturity such projections arise from cells that are concentrated in the ganglionic regions at either end of the trunk (Bowers and Zigmond, 1981).

Dispersed pattern of ganglion cell maturation. Mitotic activity is not enhanced in any particular portion of the developing superior cervical ganglion, nor do cells in any one region of the ganglion begin to produce axons or dendrites ahead of cells in other regions. Furthermore, cells in various stages of development may be found near one another at any given age. These findings are consistent with a spatially as well as temporally diffuse pattern of ganglion cell production and maturation (cf. Hendry, 1977; Claude et al., 1982). Cells retain their relative positions between E14 and maturity (Fig. 9; cf. Purves, 1975; Bowers and Zigmond, 1979); thus, simply based on the pattern of cell development, it seems unlikely that any one portion of the ganglion might be preferred over another as a site for synapse formation by preganglionic axons. Indeed, given that the specificity of ganglionic synapses in maturity is largely independent of neuronal position within the ganglion (Njå and Purves, 1977a; Lichtman et al., 1979; Purves and Wigston, 1983), the present results also appear to rule out the possibility that specific innervation derives from an early topographic pattern in the ganglion that is obscured by later development. Rather, a mechanism unrelated to cell position within the ganglion probably promotes the formation of 

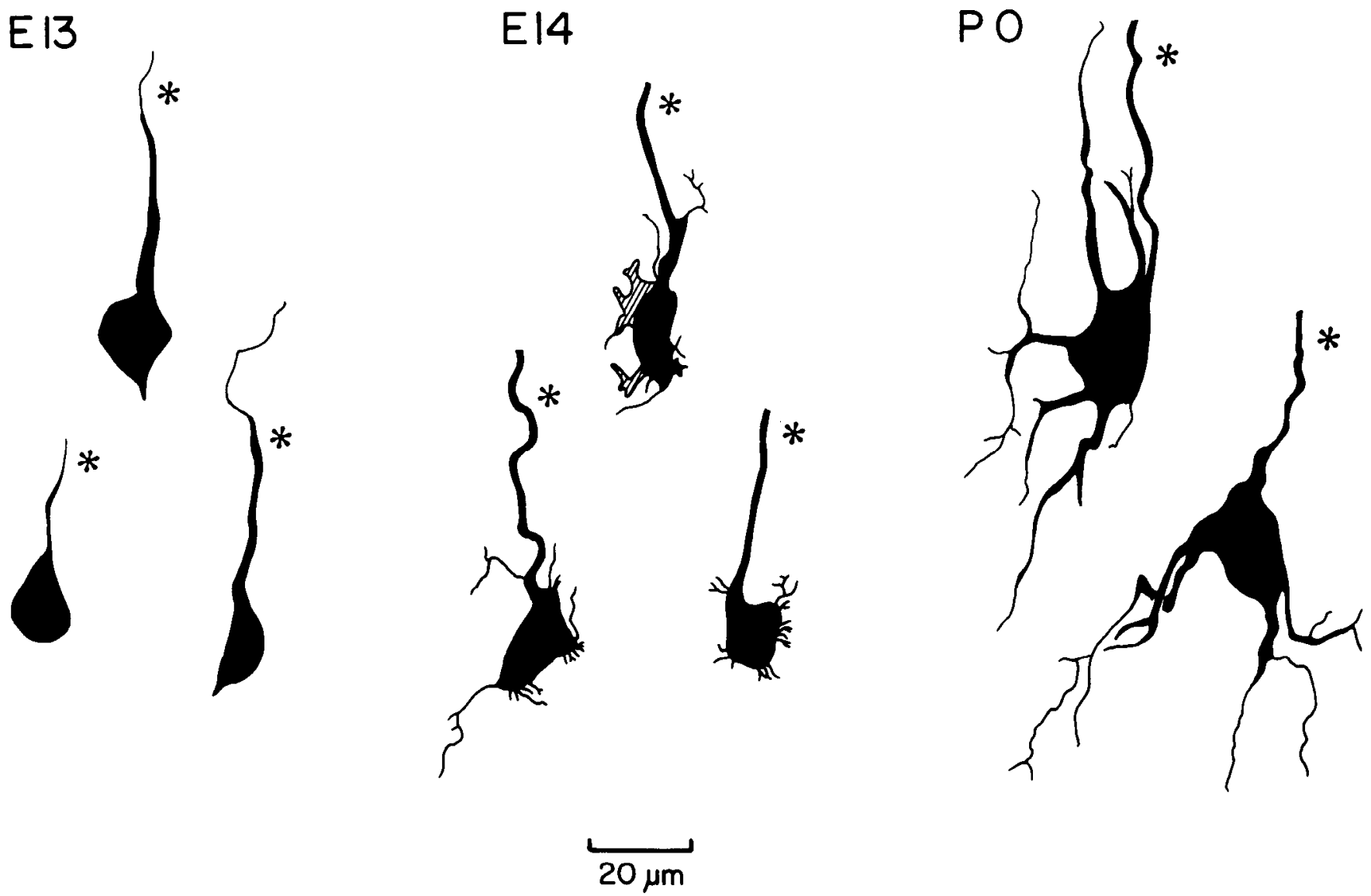

Figure 13. Dendritic growth in the superior cervical ganglion. Camera lucida drawings of cell bodies completely contained in single 50- $\mu \mathrm{m}$ sections; rostral is up for each cell. In all cases, HRP was injected into the rostral pole of the ganglion, and reaction product filled the cells diffusely. Asterisks indicate the proximal part of axons; fibers running rostrally emerge directly from the rostral portion of each cell body. Cells on E13 have prominent axons but relatively smooth somata (see also Fig. 8). Cells on E14 bear numerous processes. Some of these are thin and short, whereas others are broad sheets (shading); the longer processes are presumably rudimentary dendrites. By birth (PO), the shorter processes seen on E14 have either regressed or grown into dendrites. Some ganglion cells from the neonate already possess approximately the adult number of primary dendrites, although the adult length of these processes has not yet been reached (D. Purves and J. W. Lichtman, unpublished observation). The cells shown here illustrate the general level of dendritic development for three particular ages. At each age, however, less advanced cells are also encountered.

appropriate connections (Rubin, 1985a, b). Similar mechanisms may account as well for accurate regeneration in the adult sympathetic system (Njă and Purves, 1977b, 1978).

Axonal outgrowth from superior cervical ganglion cells. Some ganglion cells elaborate axons as early as E12 (Fig. 7), about the time when the first cells leave the mitotic cycle (Claude et al., 1982). Additionally, the number of postganglionic axons in the internal carotid nerve rises sharply around E15, close to the time when the bulk of ganglion cells are generated ( $P$. Claude, personal communication). These findings suggest that axon extension begins soon after a ganglion cell leaves the mitotic cycle. Some cells seem to extend their axons only near the end of gestation, consistent with the observation that a low level of proliferation still occurs at this age (Hendry, 1977). Few, if any, preganglionic fibers are present when the first ganglion cell axons appear (Rubin, 1985a), and thus are not likely to influence the initial stages of postganglionic outgrowth.

Axons from the superior cervical ganglion reach relatively remote destinations by $E 15$ or E16 (Fig. 12). This demonstrably rapid outgrowth stands in contrast to previous estimates based on the detection of postganglionic fibers using formaldehyde-induced catecholamine fluorescence. Such studies (see, for example, De Champlain et al., 1970) have consistently reported the first adrenergic fibers in sympathetic targets of the rat near the end of gestation or early in postnatal life. The adrenergic phenotype begins to develop around E12 (Cochard et al., 1979; Teitelman et al., 1979), at the same time that ganglion cell axons emerge; thus, growing postgan- glionic axons may contain levels of catecholamines below the sensitivity of the fluorescence assay. The arrival of postganglionic axons in the periphery days earlier than previously estimated also suggests that trophic interactions between ganglion cells and their targets may begin at a correspondingly early time.

Several observations indicate that the growth of the postganglionic axon is closely regulated. First, both early and late in gestation, ganglion cells possess only a single axon. Second, the point of axon emergence from the cell body usually coincides with the direction of subsequent axon extension. Third, axons do not appear to branch within the ganglion and, even at early times, project out a single major postganglionic nerve, suggesting that axons leave the ganglion without collateral exploration of alternative pathways. In fact, little ramification was seen anywhere along the peripheral course of the fetal postganglionic fibers, consistent with the linear orientation of the growing axon tip (Fig. 10) and the tendency for fibers to employ other axons as a substrate for growth (Fig. 11). Finally, the present study indicates that the earliest axons to reach targets in the head follow appropriate peripheral pathways; thus, it is likely that postganglionic projections develop along adult lines from the outset (see also Landmesser and Pilar, 1972; Noden, 1980; Honig, 1982). The guidance of the first axons to their end-organs is not understood, although it is of interest to note that remote peripheral targets in the adult are first contacted by axons growing over relatively short distances in the fetus. These initial projections are no doubt main- 
tained as the fetus enlarges (cf. Bray, 1984) and, thus, may lay out a route of extension for late-emerging fibers.

Dendritic outgrowth in the superior cervical ganglion. Dendrites first appcar on E14, after sympathetic ganglion cells develop axons. The stimulus for dendritic outgrowth is not known, but the prior extension of a cell's axon suggests the possibility of an early retrograde influence of peripheral tissues upon the development of dendrites. Preganglionic axons may also play a role in the growth of dendrites, since these fibers enter the superior cervical ganglion in significant numbers beginning around E14 (Rubin, 1985a), as dendrites appear. Even the first-formed dendrites receive preganglionic synaptic contacts, and as dendrites mature, they appear to be preferred over cell bodies as sites for synaptogenesis (Rubin, 1985b).

The development of dendrites is of additional interest because the complexity of the dendritic tree may determine the number of different preganglionic inputs that ultimately innervate a given cell (Hume and Purves, 1981; Forehand and Purves, 1984). The finding that some ganglion cells of the newborn rat already bear approximately the mature number of primary dendrites (range of 3 to 10 , compared to 4 to 14 in the adult rat; Purves and Lichtman, 1983) indicates that regulation of synaptic convergence probably begins well before birth.

Overall timing of ganglion cell maturation. Much of the work reported here has focused on the earliest ganglion cells to reach particular stages, a population that represents only a small fraction of the total number of neurons ultimalely generated. The first ganglion cells emerge from the mitotic cycle around E12 (Claude et al., 1982) and presumably generate the postganglionic axons that have been observed at this age. It is reasonable to assume that the same cells also produce the first dendrites in the ganglion, seen on E14. Thus, a rough developmental sequence for these cells would be: exit from mitosis (birth date), followed by axon initiation within 1 day, and dendrite initiation within 1 more day.

Applying the above sequence to the ganglion as a whole, it is apparent that the number of cells that have begun to grow both axons and dendrites should be related to the number of cells that have left the mitotic cycle 2 or more days previously. The peak of neuronal birth dates in the ganglion occurs around E14 to E15 (P. Claude, personal communication). Thus, by $\mathrm{E} 17(\mathrm{E} 15+2)$, the bulk of ganglion cells should bear both axons and dendrites. Cells with recent birth dates will have only just reached this stage, whercas older cells will be further advanced. This prediction has not been quantitatively evaluated, but HRP labeling confirms that on E17 some cells with axons have only rudimentary dendrites, whereas other cells have both axons and substantial dendrites. How this sequence of maturation occurs in relationship to the ingrowth of presynaptic axons from the spinal cord, and how synapses form upon the developing ganglion cells, will be explored in the following reports (Rubin, 1985a, b).

\section{References}

Albrecht, M. (1954) Mounting frozen sections with gelatin. Stain Tech. 29: 89-90.

Altman, J., and S. A. Bayer (1982) Development of the cranial nerve ganglia and related nuclei in the rat. Adv. Anat. Embryol. Cell Biol. 74: 1-89.

Barry, A. (1951) The aortic arch derivatives in the human adult. Anat. Rec. 117: 221-238.

Bowers, C. W., and R. E. Zigmond (1979) Localization of neurons in the rat superior cervical ganglion that project into different postganglionic trunks. J. Comp. Neurol. 185: 381-392.

Bowers, C. W., and R. E. Zigmond (1981) Sympathetic neurons in lower cervical ganglia send axons through the superior cervical ganglion. Neuroscience 6: 1788-1791.

Bray, D. (1984) Axonal growth in response to experimentally applied mechanical tension. Dev. Biol. 102: 379-389.

Christie, G. A. (1964) Developmental stages in somite and post-somite rat embryos, based on external appearance, and including some features of the macroscopic development of the oral cavity. J. Morphol. 114: 163286.
Claude, P., L. E. Lillien, I. Parada, and S. K. Presto (1982) Cell birthdays in the sympathoadrenal system: Relation to survival and differentiation in dissociated cell culture. Soc. Neurosci. Abstr. 8: 634.

Cochard, P., M. Goldstein, and I. B. Black (1979) Initial development of the noradrenergic phenotype in autonomic neuroblasts of the rat embryo in vivo. Dev. Biol. 71: 100-114.

D'Amico-Martel, A., and D. M. Noden (1983) Contributions of placodal and neural crest cells to avian cranial peripheral ganglia. Am. J. Anat. 166: 445-468.

De Champlain, J., T. Malmfors, L. Olson, and Ch. Sachs (1970) Ontogenesis of peripheral adrenergic neurons in the rat: Pre-and postnatal observations. Acta Physiol. Scand. 80: 276-288.

Douglas, W. W., D. W. Lywood, and R. W. Straub (1960) On the excitant effect of acetyicholine on structures in the preganglionic trunk of the cervical sympathetic: With a note on the anatomical complexities of the region. J. Physiol. (Lond.) 153: 250-264.

Fernholm, M. (1971) On the development of the sympathetic chain and the adrenal medulla in the mouse. Z. Anat. Entwicklungsgesch. 133: 305317.

Forehand, C. J., and D. Purves (1984) Regional innervation of rabbit ciliary ganglion cells by the terminals of preganglionic axons. J. Neurosci. 4: 112.

Frank, E., W. A. Harris, and M. B. Kennedy (1980) Lysophosphatidyl choline facilitates labeling of CNS projections with horseradish peroxidase. $\mathrm{J}$. Neurosci. Methods 2: 183-189.

Hammond, W. S., and C. L. Yntema (1947) Depletions in the thoraco-lumbar sympathetic system following removal of neural crest in the chick. J. Comp. Neurol. 86: 237-265.

Hanker, J. S., P. E. Yates, C. B. Metz, and A. Rustioni (1977) A new specific, sensitive and non-carcinogenic reagent for the demonstration of horseradish peroxidase. Histochem. J. 9: 789-792.

Hendry, I. A. (1977) Cell division in the developing sympathetic nervous system. J. Neurocytol. 6: 299-309.

Honig, M. G. (1982) The development of sensory projection patterns in embryonic chick hindlimb. J. Physiol. (Lond.) 330: 175-202.

Hume, R. I., and D. Purves (1981) Geometry of neonatal neurones and the regulation of synapse elimination. Nature 293: 469-471.

Kalt, M. R., and B. Tandler (1971) A study of fixation of early amphibian embryos for electron microscopy. J. Ultrastruct. Res. 36: 633-645.

Landmesser, L. (1978) The distribution of motoneurones supplying chick hind limb muscles. J. Physiol. (Lond.) 284: 371-389.

Landmesser, L., and G. Pilar (1972) The onset and development of transmission in the chick ciliary ganglion. J. Physiol. (Lond.) 222: 691-713.

Langford, L. A., and R. E. Coggeshall (1980) The use of potassium ferricyanide in neural fixation. Anat. Rec. 197: 297-303.

LeDouarin, N. (1982) The Neural Crest, Cambridge University Press, Cambridge, England.

Levi-Montalcini, R. (1949) The development of the acoustico-vestibular centers in the chick embryo in the absence of the afferent root fibers and of descending fiber tracts. J. Comp. Neurol. 91: 209-241.

Lichtman, J. W., and D. Purves (1980) The elimination of redundant preganglionic innervation to hamster sympathetic ganglion cells in early post-natal life. J. Physiol. (Lond.) 301: 213-228.

Lichtman, J. W., D. Purves, and J. W. Yip (1979) On the purpose of selective innervation of guinea-pig superior cervical ganglion cells. J. Physiol. (Lond.) 292: $69-84$

Lutz, G. (1968) Die Entwicklung des Halssympathicus und des Nervus vertebralis. Z. Anat. Entwicklungsgesch. 127: 187-200.

Mihalik, P. V. (1940) Untersuchungen über die Entwicklung des sympathischen Nervensystems. Anat. Anz. 89: 241-296.

Njå, A., and D. Purves (1977a) Specific innervation of guinea-pig superior cervical ganglion cells by preganglionic fibres arising from different levels of the spinal cord. J. Physiol. (Lond.) 264: 565-583.

Njå, A., and D. Purves (1977b) Re-innervation of guinea-pig superior cervical ganglion cells by preganglionic fibres arising from different levels of the spinal cord. J. Physiol. (Lond.) 272: 633-651.

Njä, A., and D. Purves (1978) Specificity of initial synaptic contacts made on guinea-pig superior cervical ganglion cells during regeneration of the cervical sympathetic trunk. J. Physiol. (Lond.) 281: 45-62.

Noden, D. M. (1980) Somatotopic organization of the embryonic chick trigeminal ganglion. J. Comp. Neurol. 190: 429-444.

Purves, D. (1975) Functional and structural changes in mammalian sympathetic neurones following interruption of their axons. J. Physiol. (Lond.) 252: 429-463.

Purves, D., and J. W. Lichtman (1983) The relationship of convergence and 
postsynaptic geometry in mammalian sympathetic ganglia. Soc. Neurosci. Abstr. 9: 320

Purves, D., and D. J. Wigston (1983) Neural units in the superior cervica ganglion of the guinea-pig. J. Physiol. (Lond.) 334: 169-178.

Rubin, E. (1982) Embryonic development of the rat superior cervical ganglion Soc. Neurosci. Abstr. 8: 6

Rubin, E. (1985a) Development of the rat superior cervical ganglion: Ingrowth of preganglionic axons. J. Neurosci. 5: 685-696.

Rubin, E. (1985b) Development of the rat superior cervical ganglion: Initial stages of synapse formation. J. Neurosci. 5: 697-704.

Teitelman, G., H. Baker, T. H. Joh, and D. J. Reis (1979) Appearance of catecholamine-synthesizing enzymes during development of rat sympathetic nervous system: Possible role of tissue environment. Proc. Nath. Acad. Sci. U. S. A. 76: $509-513$
Tennyson, V. M. (1970) The fine structure of the axon and growth cone of the dorsal root neuroblast of the rabbit embryo. J. Cell Biol. 44: 62-79.

Terry, L. C., G. M. Bray, and A. J. Aguayo (1974) Schwann cell multiplication in developing rat unmyelinated nerves-A radioautographic study. Brain Res. 69: 144-148.

Weston, J. A. (1963) A radioautographic analysis of the migration and localization of trunk neural crest cells in the chick. Dev. Biol. 6: 279-310.

Wright, L. J., T. J. Cunningham, and A. J. Smolen (1983) Developmental neuron death in the rat superior cervical sympathetic ganglion: Cell counts and ultrastructure. J. Neurocytol. 12: 727-738.

Yip, J. W. (1983) Formation of paravertẹbral sympathetic chain ganglia in chick embryos. Soc. Neurosci. Abstr. 9: 937 